\title{
Muscarinic $M_{2}$ receptor promotes vasopressin synthesis in mice supraoptic nuclei
}

\author{
Hiroshi Nagano', Yuki Sobue², Hayato Matsuyama², Shoichiro Saito³, Hiroki Sakai4, Firoj Alom', \\ Yasuyuki Tanahashi' ${ }^{5}$ Toshiaki Ishii6 and Toshihiro Unno ${ }^{2}$ \\ 1Department of Pathogenetic Veterinary Science, United Graduate School of Veterinary Science, Gifu University, Gifu, Japan \\ 2Laboratory of Veterinary Pharmacology, Faculty of Applied Biological Science, Gifu University, Gifu, Japan \\ ${ }^{3}$ Laboratory of Veterinary Anatomy, Faculty of Applied Biological Science, Gifu University, Gifu, Japan \\ 4Laboratory of Veterinary Pathology, Faculty of Applied Biological Science, Gifu University, Gifu, Japan \\ ${ }^{5}$ Department of Animal Medical Sciences, Faculty of Life Science, Kyoto Sangyo University, Kyoto, Japan \\ ${ }^{6}$ Department of Basic Veterinary Medicine, Obihiro University of Agriculture and Veterinary Medicine, Obihiro, Japan \\ Correspondence should be addressed to T Unno: tunno@gifu-u.ac.jp
}

\section{Abstract}

Muscarinic acetylcholine receptors have been suggested to be implicated in argininevasopressin secretion because intracerebroventricular muscarinic agonist administration induces arginine-vasopressin release into the circulation. Although which subtype is involved in the regulation of arginine-vasopressin secretion is unclear, $\mathrm{M}_{2}$ receptors have been reported to be highly expressed in the hypothalamus. In the present study, $M_{2}$ receptor-knockout mice were used to elucidate whether $M_{2}$ receptor regulates arginine-vasopressin synthesis in the paraventricular nuclei and supraoptic nuclei of the hypothalamus. The number of arginine-vasopressin-immunoreactive neurons in $\mathrm{M}_{2}$ receptor-knockout mice was significantly decreased in the supraoptic nuclei, but not in the paraventricular nuclei compared with wild-type mice. Plasma arginine-vasopressin level in $\mathrm{M}_{2}$ receptor-knockout mice was also significantly lower than in the wild-type mice. Urinary volume and frequency as well as water intake in $\mathrm{M}_{2}$ receptor-knockout mice were significantly higher than those in wild-type mice. The $\mathrm{V}_{2}$ vasopressin receptor expression in kidneys of $\mathrm{M}_{2}$ receptor-knockout mice was comparable with that of wild-type mice, and increased urination in $\mathrm{M}_{2}$ receptor-knockout mice was significantly decreased by administration of desmopressin, a specific $V_{2}$ receptor agonist, suggesting that $\mathrm{V}_{2}$ receptors in the kidneys of $\mathrm{M}_{2}$ receptor-knockout mice are intact. These results suggest that $M_{2}$ receptors promote arginine-vasopressin synthesis in the supraoptic nuclei and play a role in the regulation and maintenance of body fluid.

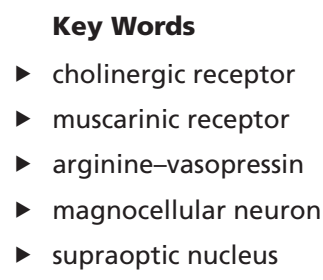

Key Words

- cholinergic receptor

- muscarinic receptor

- arginine-vasopressin

- supraoptic nucleus (2018) 237, 207-216

\section{Introduction}

Arginine-vasopressin (AVP), an antidiuretic hormone, is synthesized by magnocellular neurosecretory cells (MNCs) in the paraventricular nuclei (PVN) and supraoptic nuclei (SON) of the hypothalamus and subsequently released from nerve terminals in the posterior pituitary into the blood circulation. AVP maintains body fluid homeostasis by stimulating water reabsorption via vasopressin $V_{2}$ receptors in the renal collecting tubule. Synthesis and secretion of AVP are regulated by complex mechanisms that are mediated by various neurotransmitters. Involvement of cholinergic neurons in AVP production is well documented. Some pharmacological studies have 
shown that nicotinic receptors induce MNC excitation and promote AVP release (Armstrong 1982, Hatton et al. 1983, Zaninetti et al. 2002), whereas other studies have revealed the participation of muscarinic receptors in AVP release (Iitake et al. 1986, Michels et al. 1991, Shen \& Sun 1995). Particularly in the SON, cholinergic neurons project to MNCs (Rao et al. 1987, Wang et al. 2015), and muscarinic receptors are expressed in this region (Rotter et al. 1979, Meeker et al. 1988). Moreover, microinfusion of muscarinic agonist into the SON increases c-fos expression in MNCs (Shen \& Sun 1995) and decreases urinary volume (Mori et al. 1994), suggesting muscarinic regulation of AVP release in the SON region.

Plasma hyperosmolality is known as a physiological stimulation that promotes AVP secretion. The subfornical organ (SFO) and median preoptic nucleus of the hypothalamus are regions controlling plasma osmolality and drinking behavior (Leng et al. 1989, Fitzsimons 1998). Anatomical evidence showed that these regions project cholinergic nerve terminals to the PVN and SON (Oldfield et al. 1991, Xu et al. 2003), and it was indicated that they activate AVP neurons via muscarinic receptors, but not nicotinic receptors (Xu et al. 2001a). In addition, AVP secretion is also related to blood pressure, which is regulated by the cardiovascular system. Previous studies have demonstrated that muscarinic receptor activation in the bed nucleus of the stria terminalis (BNST) and the posterior hypothalamic nuclei caused a pressor response (Xiao \& Brezenoff 1988, Martin 1996, Alves et al. 2007, 2011).

Muscarinic receptors are classified into five subtypes, $\mathrm{M}_{1}$ to $\mathrm{M}_{5}$, and colocalized in various organs. However, which subtype is implicated in AVP production remains to be identified because no reagent has a specific affinity for each subtype. Although the $\mathrm{M}_{2}$ receptor is known to be abundantly expressed in the hypothalamus (Vilaró et al. 1993, Wei et al. 2002, Oki et al. 2005), and previous reports have shown that the $\mathrm{M}_{2}$ receptor in the brain induced drinking behavior (Hagan et al. 1987) and a pressor response resulted from increase in circulating AVP (Brezenoff et al. 1988, Xiao \& Brezenoff 1988, Alves et al. 2007), its detailed function is unclear.

In the present study, transgenic mice lacking the $\mathrm{M}_{2}$ subtype of muscarinic receptor were used to elucidate if the $\mathrm{M}_{2}$ receptor regulates AVP production. We assessed the capability of AVP synthesis and secretion by counting the number of AVP-immunoreactive (AVP-IR) neurons in the PVN and SON and measuring plasma AVP levels. Furthermore, AVP-mediated antidiuresis was estimated from parameters of drinking and urination. The results suggest that $\mathrm{M}_{2}$ receptors contribute to AVP synthesis in the SON.

\section{Materials and methods}

Animals

Female $\mathrm{M}_{2}$ receptor-knockout $\left(\mathrm{M}_{2} \mathrm{KO}\right)$ mice (3-4 months old), weighing $25.1 \pm 1.0 \mathrm{~g}$ (mean \pm s.e.m.), and their corresponding wild-type (WT) mice, weighing $27.9 \pm 1.0 \mathrm{~g}$, were used in all experiments. The generation of $\mathrm{M}_{2} \mathrm{KO}$ mice has been described previously (Gomeza et al. 1999, Struckmann 2003). The genetic background of mice used in the present study was $129 \mathrm{~J} 1(50 \%) \times \mathrm{CF} 1(50 \%)$ for the $\mathrm{M}_{2} \mathrm{KO}$ and WT mice. The animals were housed in a temperature-controlled room at $22-25^{\circ} \mathrm{C}$ under a 12 -h light/darkness cycle (07:00-19:00 h). The animals were allowed to access the chow and distilled water ad libitum. All experimental procedures were performed based on the guidelines approved by the local animal ethics committee of the Faculty of Applied Biological Science, Gifu University.

\section{AVP immunohistochemistry}

The experiment was performed between 09:00 and $12: 00 \mathrm{~h}$ to avoid the diurnal variations in AVP synthesis. The animals were anesthetized with ketamine $(80 \mathrm{mg} / \mathrm{kg}$, i.p.) and xylazine $(10 \mathrm{mg} / \mathrm{kg}$, i.p.) and immediately perfused intracardially with heparinized saline, followed by $4 \mathrm{w} / \mathrm{v} \%$ paraformaldehyde in $0.1-\mathrm{M}$ phosphate buffer (Wako Pure Chemical Industries). The brain was removed and postfixed in the same fixative overnight at $4^{\circ} \mathrm{C}$. The tissues were dehydrated in a graded series of ethanol, cleared in xylene and paraffin embedded. Coronal sections of 5- $\mu \mathrm{m}$ thickness containing the PVN and/or SON were cut between the optic chiasm and median eminence and collected in five alternate slices. They were deparaffinized in xylene and rehydrated in a graded series of ethanol. The sections were rinsed thrice for $5 \mathrm{~min}$ in PBS with $0.1 \mathrm{v} / \mathrm{v} \%$ Triton X-100 (PBST) and were incubated for $30 \mathrm{~min}$ at room temperature with blocking buffer, including $0.1 \mathrm{v} / \mathrm{v} \%$ normal goat serum, $1 \mathrm{v} / \mathrm{v} \%$ bovine serum albumin and $0.1 \mathrm{w} / \mathrm{v} \%$ sodium azide. After being rinsed in PBST, they were incubated overnight at $4^{\circ} \mathrm{C}$ with rabbit anti-AVP polyclonal antibody (1:2500, AB1565, Chemicon International). They were rinsed in PBST and incubated for $30 \mathrm{~min}$ at room temperature with biotinylated anti-rabbit IgG antibody (1:1000, Sigma-Aldrich), and then for $30 \mathrm{~min}$ at room temperature with peroxidase-labeled avidin-biotin complex (1:400, Vectastain Elite ABC Kit, Vector Laboratories, Burlingame, CA, USA). AVP immunoreactivity was visualized in 
Tris- $\mathrm{HCl}$ containing $0.02 \mathrm{w} / \mathrm{v} \%$ diaminobenzidine and $0.003 \mathrm{w} / \mathrm{v} \% \mathrm{H}_{2} \mathrm{O}_{2}$ for $10 \mathrm{~min}$, and the sections were subsequently stained with hematoxylin as counterstain. After being dehydrated in a graded series of ethanol and cleared in xylene, they were mounted with coverslips.

To count the number of AVP-IR neurons, digitalized images, including the PVN and/or SON area were obtained by using a digital camera (Pro 600ES, Pixera Corporation, Santa Clara, CA, USA) installed on a microscope. To discriminate between the AVP-positive neurons and other neurons, a threshold value for the intention of immunoreactivity was set by using the image software ImageJ (National Institutes of Health, Bethesda, MD, USA). The numbers of AVP-IR neurons were counted from an observer's eyes. The magnocellular region of the PVN was divided based on the mouse brain in stereotaxic coordinates by Paxinos \& Franklin (2004). The differences between the right and left regions of each nucleus were not distinguished.

\section{Plasma AVP level}

Mice were anesthetized with diethyl ether. Blood samples were collected via the heart in chilled tubes containing ethylene diamine tetraacetic acid and were then centrifuged $(2000 \mathrm{~g}, 10 \mathrm{~min})$. Supernatants were left at $-20^{\circ} \mathrm{C}$ and used to quantify plasma AVP levels by radioimmunoassay consigned to Monolis Co., Ltd. (Tokyo, Japan).

\section{Drinking and urination test}

Mice were acclimatized in metabolic cages for a day before an experimental day. Measurements of water intake, urinary volume and urinary frequency were obtained by putting the upper chambers of the metabolic cages (3600M021, Tecniplast, VA, Italy) on a windbreaking holder covering an electronic balance. A metal mesh placed at the bottom of the upper chamber was subjected to water-repellent treatment. Urinary parameters were recorded at every $1 \mathrm{~s}$ by using a measurement software (Salto In TIMER, Sartorius Mechatronics, Göttingen, Germany), which was installed in a computer connected to an electronic balance. Data were determined as urination when the recorded value was higher than $0.100 \mathrm{~g}$, following the report by Yamamoto et al. (2009). If plurality of data recorded as urination was obtained within 10 s, they were decided as a single urination. Water intake was estimated by comparing a weight of the water bottle before and after measurements. These experiments were conducted from 19:00 to 13:00 h the following day. The animals were not allowed to take chow during the experiments.

\section{Blood chemistry}

Blood samples were collected via a caudal vein in chilled tubes containing heparin, which were then centrifuged $(1500 \boldsymbol{g}, 5 \mathrm{~min})$. Serum was analyzed for biochemistry parameters by the biochemical analyzer (FUJI DRICHEM 7000V, FUJIFILM, Tokyo, Japan): blood urea nitrogen (BUN), glucose (GLU), sodium $(\mathrm{Na})$, potassium $(\mathrm{K})$, calcium $(\mathrm{Ca})$. The approximate values of plasma osmolality were calculated by substituting the values of $\mathrm{Na}, \mathrm{K}, \mathrm{GLU}$ and BUN for the following formula (Dorwart \& Chalmers 1975):

$$
\begin{aligned}
\text { Calculated osmolality }= & 2[\mathrm{Na}]+2[\mathrm{~K}]+[\mathrm{GLU}] / 18 \\
& +[\mathrm{BUN}] / 2.8(\mathrm{mosmol} / \mathrm{kg})
\end{aligned}
$$

\section{Urine analysis}

Urine collected by manual compression of the urinary bladder was centrifuged $(1500 \boldsymbol{g}, 5 \mathrm{~min})$, and the supernatant was then analyzed for urine-specific gravity by a refractometer (UR-JE, ATAGO, Tokyo, Japan).

Testing for the presence of hemoglobin, bilirubin, urobilinogen, ketones, proteins, glucose and nitrite was performed using urine test strips (Uropaper III, Eiken Chemical, Tokyo, Japan).

\section{Histopathological analysis}

The animals were killed by cervical dislocation, and the following organs were removed: kidney, urinary bladder, thyroid glands, adrenal glands, liver and heart. These organs were trimmed and fixed in $4 \mathrm{w} / \mathrm{v} \%$ paraformaldehyde in 0.1-M phosphate buffer overnight at $4^{\circ} \mathrm{C}$. The tissues were processed for paraffin sectioning as mentioned above and cut into $4-\mu \mathrm{m}$ sections. The sections were stained with hematoxylin and eosin and then mounted with coverslips. They were used to detect pathological lesions by using a light microscope.

\section{$V_{2}$ immunohistochemistry}

Paraffin sections of the kidney were made as mentioned earlier. Immunohistochemistry of vasopressin $V_{2}$ receptors $\left(\mathrm{V}_{2} \mathrm{R}\right)$ was performed to confirm the presence 
of $\mathrm{V}_{2} \mathrm{R}$ similar to that of AVP. The rabbit anti- $\mathrm{V}_{2}$ receptor polyclonal antibody (1:100, Bioss, Woburn, MA, USA) was used as a primary antibody. The second antibody was the HRP-labeled anti-rabbit antibody (1:1, En Vision System HRP, Dako).

\section{Enzyme-linked immunosorbent assay}

ELISA was conducted to evaluate the $V_{2} R$ expression in the kidney by using anti- $\mathrm{V}_{2} \mathrm{R}$ antibody. The kidneys were homogenized with 1-mL CelLytic MT (Sigma-Aldrich) per 50 -mg tissue. After centrifugation $(15,000 \boldsymbol{g}, 10 \mathrm{~min})$, the supernatants were collected as sample solutions.

For calibration curve construction, the BSA solution was diluted with distilled water to appropriate concentrations, and the absorbance was measured at $595 \mathrm{~nm}$ by using a spectrophotometer (U-1100, HITACHI). Absorbance was measured by using the protein assay CBB solution (Nakalai-tesque, Kyoto, Japan) and by following the manual. The sample absorptions were measured similarly, and the protein concentrations were calculated from the calibration curve.

The sample solutions diluted $(10 \mu \mathrm{g} / \mathrm{mL})$ with $0.05-\mathrm{M}$ carbonate-bicarbonate buffer ( $\mathrm{pH}$ 9.6) were dispensed $(50 \mu \mathrm{L} /$ well $)$ into microtiter plates with 96 wells and incubated overnight at $4^{\circ} \mathrm{C}$. After being washed with PBST, they were blocked with PBS containing $3 \mathrm{w} / \mathrm{v} \%$ skim milk for $1 \mathrm{~h}$ at $37^{\circ} \mathrm{C}$. After washing, they were incubated with rabbit anti- $\mathrm{V}_{2}$ receptor polyclonal antibody (1:30; Santa Cruz Biotechnology) for $1 \mathrm{~h}$ at $37^{\circ} \mathrm{C}$. The second antibody used in the immunohistochemistry of $\mathrm{V}_{2} \mathrm{R}(1: 1)$ was added $\left(50 \mu \mathrm{L} /\right.$ well) and incubated for $1 \mathrm{~h}$ at $37^{\circ} \mathrm{C}$ after washing. After being washed six times, the substrate solution was added $(100 \mu \mathrm{L} /$ well $)$ to the wells, and the plates were incubated for $1 \mathrm{~h}$ at room temperature in the dark. After the substrate reaction was stopped, the absorbance was read at $415 \mathrm{~nm}$ with a microplate reader (model 680, Bio-Rad Laboratories).

\section{Desmopressin test}

Desmopressin, a synthetic AVP analog with a high affinity for $V_{2} R$, was used to evaluate $V_{2} R$ reactivity in the kidneys. The animals were loaded with distilled water $(15 \mathrm{~mL} / \mathrm{kg}$, p.o.) and administered with desmopressin acetate hydrate $(1 \mu \mathrm{g} / \mathrm{kg}$, i.p., Kyowa Hakko Kirin, Tokyo, Japan). Thereafter, urinary volumes were recorded for $5 \mathrm{~h}$ while avoiding of food and water intake. Control groups were treated with saline $(5 \mathrm{~mL} / \mathrm{kg}$, i.p.) instead of desmopressin.

\section{Statistical analysis}

Data were presented as the mean \pm s.E.M. Student $t$-test was used to determine significance. Values were considered significant if $P<0.05$.

\section{Results}

\section{AVP-IR neurons in the PVN and SON}

AVP-IR somata and fibers were observed in the PVN and SON of the hypothalamus in both types of mice (Fig. 1). The number of AVP-IR neurons in the PVN of $\mathrm{M}_{2} \mathrm{KO}$ mice was similar to that of WT mice (Fig. 1A and B). However, in the SON of $\mathrm{M}_{2} \mathrm{KO}$ mice, the number of AVP-IR neurons seemed to be decreased, and their individual size appeared smaller than in WT mice (Fig. 1C and D). A few small perikarya showing AVP immunoreactivity were observed in the parvocellular region of the PVN in both mice groups (not shown).

The number of AVP-IR perikarya was not different between the PVN of both strains $(343.2 \pm 45.2, n=5$, vs $313.8 \pm 37.5, n=5: P>0.05$; Fig. $2 \mathrm{~A}$ ). In contrast, AVPimmunostained perikarya were significantly decreased in the SON of $\mathrm{M}_{2} \mathrm{KO}$ mice compared with that in WT mice (2353.8 $\pm 245.4, n=5$, vs $898.2 \pm 142.4, n=5$ : $P<0.01$; Fig. $2 \mathrm{~B})$.

\section{Plasma AVP level and antidiuresis}

As shown in the Fig. 3, plasma AVP concentration obtained from $\mathrm{M}_{2} \mathrm{KO}$ was only approximately $30 \%$ of that from WT $(1029.9 \pm 233.8 \mathrm{pg} / \mathrm{mL}, n=10$, vs $341.8 \pm 105.7 \mathrm{pg} / \mathrm{mL}$, $n=8: P<0.05)$.

The absence of $\mathrm{M}_{2}$ receptors induced remarkable increases in drinking and urination. Water intake in the $\mathrm{M}_{2} \mathrm{KO}$ group was 9.6-fold higher than in the WT group $(0.69 \pm 0.12 \mathrm{~g}, n=27$, vs $10.0 \pm 0.80 \mathrm{~g}, n=8: P<0.01$; Fig. 4A). Urinary volume in $\mathrm{M}_{2} \mathrm{KO}$ mice was 14.5 -fold higher than in WT mice $(5.6 \pm 0.33 \mathrm{~g}, n=27$, vs $43.5 \pm 1.8 \mathrm{~g}$, $n=8$ : $P<0.01$; Fig. $4 \mathrm{~B}$ ), and the frequency was also 7.8 -fold higher than in WT mice $(1.2 \pm 0.13, n=27$, vs $11.5 \pm 0.80$, $n=8$ : $P<0.01$; Fig. 4 C).

\section{Plasma biochemistry and osmolality}

From the results of serum chemistry analysis, no significant differences in all parameters were found between the $\mathrm{M}_{2} \mathrm{KO}$ and WT groups (Table 1). Plasma osmolality calculated from the values of $\mathrm{Na}, \mathrm{K}, \mathrm{GLU}$ and BUN showed plasma hyperosmolality in $\mathrm{M}_{2} \mathrm{KO}$ mice (325.6 $\pm 1.4, n=13$, vs $331.3 \pm 2.3 \mathrm{mosmol} / \mathrm{kg}, n=8: P<0.05$; Fig. 5 ). 

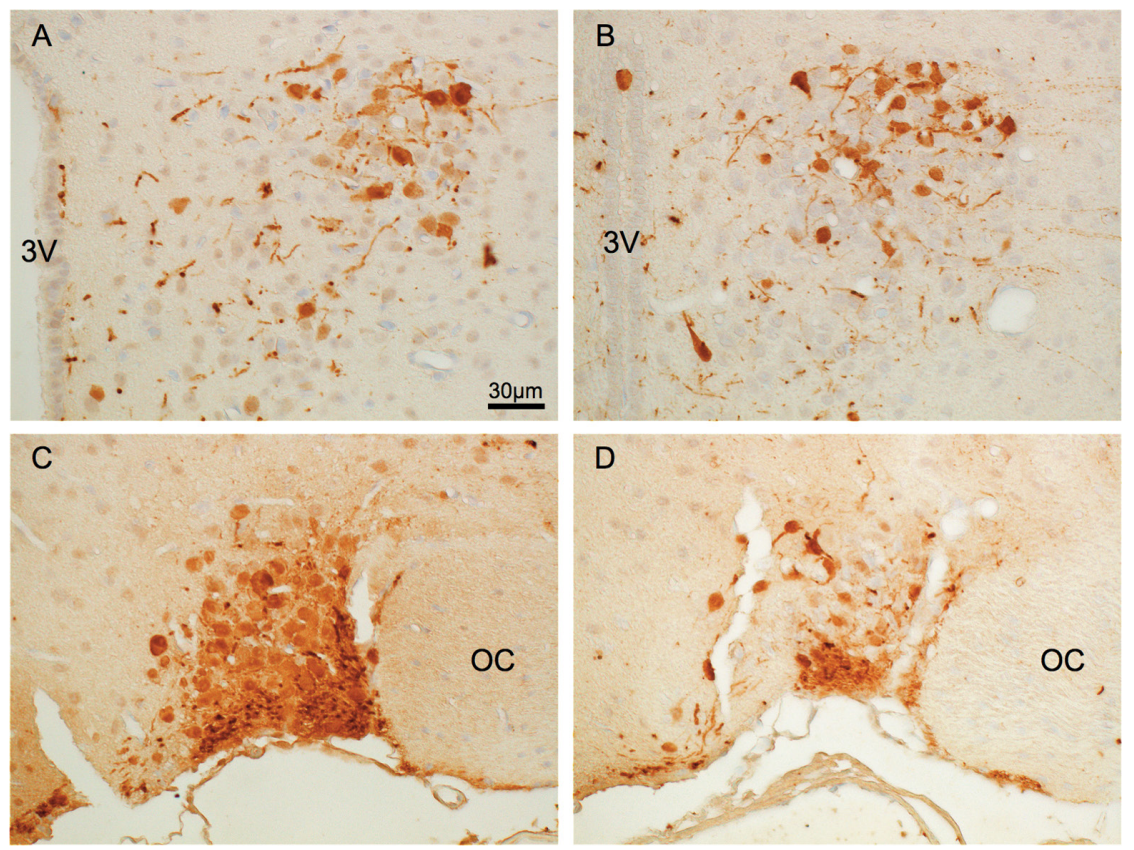

\section{Figure 1}

Localization of AVP-IR cells in the PVN (A and B) and SON ( $C$ and $D$ ) of WT ( $A$ and $C$ ) and $M_{2} K O$ mice ( $B$ and $D)$. AVP immunoreactivity was detected in perikarya and fibers. 3V, third ventricle; OC, optic chiasm. Scale bar indicates $30 \mu \mathrm{m}$. A full color version of this figure is available at https://doi.org/10.1530/JOE-17-0630.
In the $\mathrm{M}_{2} \mathrm{KO}$ group, urine-specific gravity was significantly decreased compared with the WT group $(1.07 \pm 0.03, n=27$, vs $1.04 \pm 0.05, n=8: P<0.05)$. None of the pathological components comprising hemoglobin, bilirubin, urobilinogen, ketones, proteins, glucose and nitrite were detected in the urine of both mice groups.

\section{Morphologic pathology}

Microscopic examination of the kidney, urinary bladder, thyroid glands, adrenal glands, liver and heart revealed no pathological changes in all organs of both strains (data not shown). No macroscopic lesions were found in both strains (data not shown).

\section{Expression and reactivity of $\mathrm{V}_{2} \mathrm{R}$}

The $\mathrm{V}_{2} \mathrm{R}$ immunoreactivity in the kidney of $\mathrm{M}_{2} \mathrm{KO}$ mice was found in the tubular epithelial cells (Fig. 6A(b)). This finding was similar to that of WT mice (Fig. 6A(a)). The expression levels of $\mathrm{V}_{2} \mathrm{R}$ in the kidney were shown as the absorbance obtained by ELISA. They were not significantly different between both strains $(0.756 \pm 0.058, n=6$, vs $0.923 \pm 0.067, n=6$ : $P>0.05$; Fig. 6B).

The urinary volume of the WT group was decreased by desmopressin administration. Although the urinary volume of the control group in the $\mathrm{M}_{2} \mathrm{KO}$ group was twice as much as that in WT, desmopressin administration to the $\mathrm{M}_{2} \mathrm{KO}$ group decreased the value to almost the same level with WT group treated with desmopressin
(WT: $0.63 \pm 0.17 \mathrm{~g}, n=5$ vs $0.06 \pm 0.06 \mathrm{~g}, n=6: P<0.05 ; \mathrm{M}_{2} \mathrm{KO}$ : $1.19 \pm 0.10 \mathrm{~g}, n=5$ vs $0.08 \pm 0.09 \mathrm{~g}, n=6: P<0.05$; Fig. 7 ).

\section{Discussion}

The present study suggests that the lack of $\mathrm{M}_{2}$ receptors is involved in the decrease of AVP synthesis and secretion into the systemic circulation. These results supported the previous reports indicating that muscarinic receptor activation in the brain promoted AVP secretion (Iitake et al. 1986, Gribkoff et al. 1988, Michels et al. 1991, Ghamari-Langroudi \& Bourque 2004). The AVP-IR neurons in the SON of $\mathrm{M}_{2} \mathrm{KO}$ mice were significantly
A

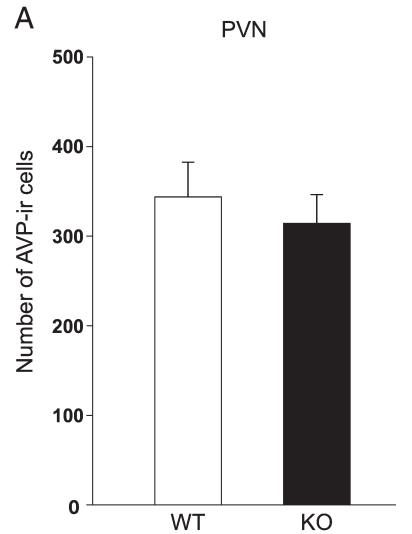

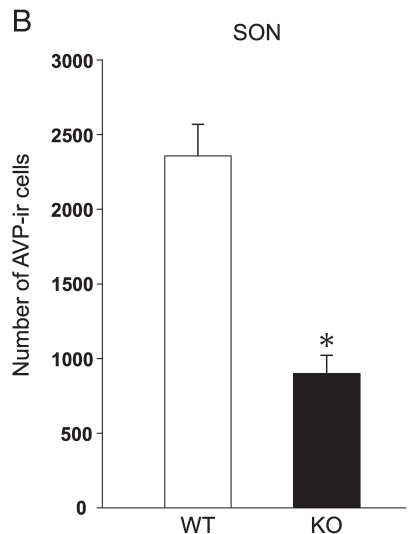

Figure 2

Number of AVP-IR cells in the PVN (A) and SON (B) of WT $(n=5)$ and $\mathrm{M}_{2} \mathrm{KO}$ mice $(n=5)$. A significant difference in the SON is found between WT and $\mathrm{M}_{2} \mathrm{KO}$ groups, but not in the PVN. ${ }^{*} P<0.05$ vs WT group. 


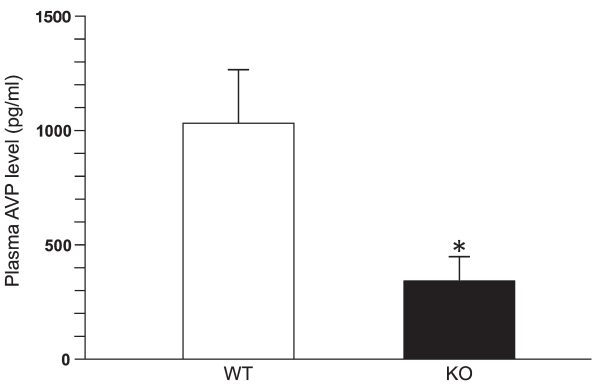

\section{Figure 3}

Plasma AVP level in WT and $\mathrm{M}_{2} \mathrm{KO}$ mice. The value in $\mathrm{M}_{2} \mathrm{KO}$ mice $(n=8)$ is significantly lower than that in WT mice $(n=10) .{ }^{*} P<0.05$ vs WT group.

less than that of WT mice, although the decreased AVP-IR neurons' number does not always mean that AVP synthesis is decreased in the SON. However, the plasma AVP level in $\mathrm{M}_{2} \mathrm{KO}$ mice was significantly lower than that in the WT mice. These findings suggested that $\mathrm{M}_{2}$ receptors can promote AVP synthesis in the SON. On the other hand, the number of AVP neurons in the PVN of the $\mathrm{M}_{2} \mathrm{KO}$ group was comparable to that of the WT group. There are several reports suggesting functional differences between the PVN and SON (Shen et al. 1992, Takahashi et al. 2001). Alves et al. have demonstrated that an increase of AVP secretion in response to microinjection of carbachol, a muscarinic agonist, into the BNST was blocked by prior injection of a neurotransmission blocker cobalt chloride into the SON but not into the PVN (Alves et al. 2011). They have also reported that a cardiovascular effect induced by carbachol into the BNST was blocked by

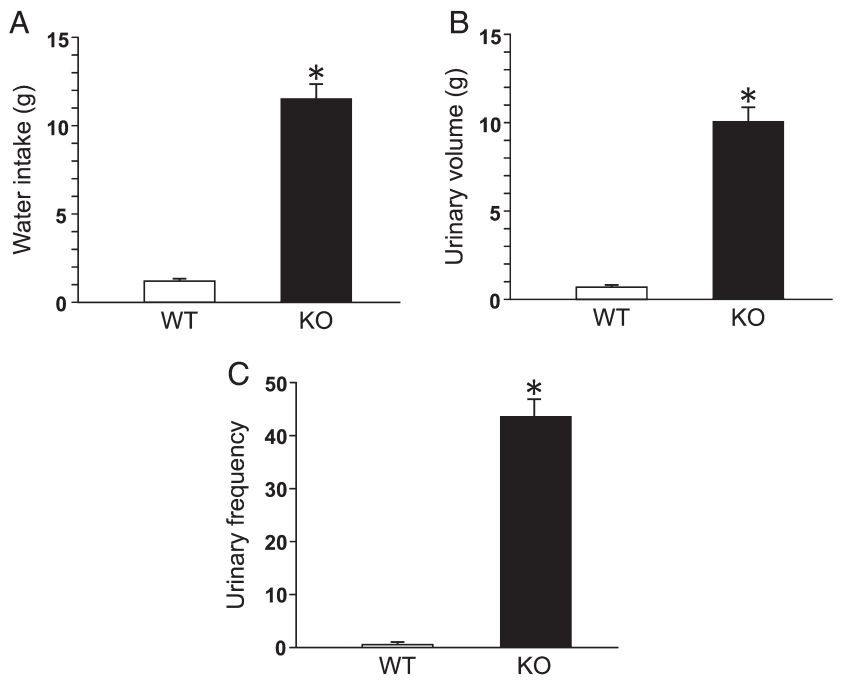

Figure 4

Effect of $M_{2}$ deficiency on urinary volume (A), urinary frequency $(B)$ and water intake (C). Recordings are performed for $18 \mathrm{~h}$ while avoiding food and drinking. In all parameters, $\mathrm{M}_{2} \mathrm{KO}$ mice $(n=8)$ showed significantly higher values than WT mice $(n=27)$. ${ }^{*} P<0.05$ vs WT group. pretreatment with $\mathrm{M}_{2}$ receptor antagonist into the BNST or i.v. pretreatment with the AVP receptor antagonist (Alves et al. 2007). These findings imply that $\mathrm{M}_{2}$ receptors in the BNST might involve neuronal pathway to the SON to mediate AVP secretion into the blood. Similar to these studies, the present results suggest that $\mathrm{M}_{2}$ receptors are involved in AVP synthesis regulation in the SON.

Some previous reports suggested that water drinking was regulated by muscarinic receptors (Mangiapane \& Simpson 1979, Hagan et al. 1987, Takahashi et al. 2001). If a deficiency of the $\mathrm{M}_{2}$ receptor facilitates drinking followed by polyuria, and excessive increase of body fluid consequently inhibits AVP secretion, plasma osmolality in $\mathrm{M}_{2} \mathrm{KO}$ mice should be decreased. In contrast, if a decrease of AVP synthesis induced by the loss of $\mathrm{M}_{2}$ receptors attenuates antidiuretic effects, which result in polyuriapolydipsia, plasma osmolality in $\mathrm{M}_{2} \mathrm{KO}$ mice should be increased. The significant increase in plasma osmolality in the $\mathrm{M}_{2} \mathrm{KO}$ group supports the latter hypothesis.

A plasma osmolality is strictly controlled in a narrow range; hence, increased osmolality in plasma potently stimulates the promotion of AVP synthesis and secretion (Martin 1996). Nevertheless, the number of AVP-positive neurons in the PVN of $\mathrm{M}_{2} \mathrm{KO}$ mice was not significantly different from that of WT mice. This suggests that the SON may play a predominant role in AVP secretion into the blood circulation. Magnocellular AVP neurons secrete AVP not only from axon terminal into the blood stream but also from somata and dendrites into the extracellular fluid of the SON and PVN (Pow \& Morris 1989, Landgraf \& Ludwig 1991, Ludwig et al. 1994). It has been observed that certain stressors such as forced swimming and social defeat induced increase of mRNA level and intranuclear AVP secretion in only the PVN but not the SON (Wotjak et al. 1996, 2001). Nonetheless, such stressors did not increase plasma AVP level. Thus, intranuclear secretion of AVP in the PVN seems to be involved in stress responses. In addition, some reports have indicated that the SON may take more responsibility for responses to stimuli such as hyperosmolality (Sherman et al. 1986, da Silveira et al. 2007) and hypovolemia (Shen et al. 1992). Therefore, magnocellular AVP neurons of the PVN are more likely to participate in stress responses than those of the SON. Conversely, AVP synthesized in the SON seems to be closely related to the homeostasis of body fluids rather than stress responses. However, there might be possibilities that we were not able to distinguish magnocellular neurons from parvocellular neurons precisely and that the difference, which should have been detected in the PVN between WT and $\mathrm{M}_{2} \mathrm{KO}$ 
Table 1 Blood serum chemistry of WT $(n=12-22)$ and $\mathrm{M}_{2} \mathrm{KO}(n=7-9)$ mice.

\begin{tabular}{lcc} 
& BUN $(\mathrm{mg} / \mathrm{dL})$ & GLU $(\mathrm{mg} / \mathrm{dL})$ \\
& $20.8 \pm 0.4$ & $141 \pm 1.4$ \\
$\mathrm{M}_{2} \mathrm{KO}$ & $23.0 \pm 0.5$ & $148 \pm 2.4$ \\
\hline
\end{tabular}

There was no significant difference between these mice strains.

groups was masked. Indeed, accurate discrimination of immunopositive MNCs from the other cells was impossible due to gathering densely even though we referred to a mice brain atlas. Further consideration is needed to conclude if the $\mathrm{M}_{2}$ receptor affects AVP synthesis and secretion in the PVN. Additionally, AVP synthesis inhibition by a lack of $\mathrm{M}_{2}$ receptors might antagonize AVP synthesis driven by increase of plasma osmolality. For elucidating this hypothesis, to assess the reactivity to a physiological stimulation, such as hypertonic saline administration, is necessary.

$\mathrm{M}_{2} \mathrm{KO}$ mice display some phenotypes in their physiological characteristics due to lacking $\mathrm{M}_{2}$ receptors from birth (Gomeza et al. 1999, Bymaster et al. 2003, Zhang 2006). Therefore, we assessed if some specific organs have specific lesions. The urinary bladder and heart are known as peripheral organs that highly express $\mathrm{M}_{2}$ receptors. However, they had no pathological finding. In fact, previous studies using $\mathrm{M}_{2} \mathrm{KO}$ mice have reported that a loss of $\mathrm{M}_{2}$ receptors did not influence of bladder contraction potently (Igawa et al. 2004, Uchiyama \& Chess-Williams 2004, Ehlert et al. 2005), and basal heart rate and blood pressure in $\mathrm{M}_{2} \mathrm{KO}$ mice were also not significantly different from that of WT (LaCroix et al. 2008). Moreover, the thyroid and adrenal glands also had no specific lesion. In addition, the liver, where AVP is metabolized, seemed not to be different between the WT and $\mathrm{M}_{2} \mathrm{KO}$ groups. We concluded that these organs were likely not to have a crucial effect on decrease of AVP synthesis observed in $\mathrm{M}_{2} \mathrm{KO}$ mice although the other inspections, such as endocrinologic or physiologic tests, were not conducted in the present study. However, we could not contradict a possibility that the number of $\mathrm{MNC}$ was diminished in $\mathrm{M}_{2} \mathrm{KO}$ mice or that the intensity of immunostaining in perikarya was decreased by accelerated axonal transportation of AVP peptides from somata to terminals. Further experiments are needed to inspect these possibilities.

In $\mathrm{M}_{2} \mathrm{KO}$ mice, water intake, urinary volume and urinary frequency were significantly increased, and urinespecific gravity was decreased compared with those of WT mice. Thus, $\mathrm{M}_{2} \mathrm{KO}$ mice had symptoms, such as diabetes insipidus. Although some other diseases, such as diabetes, psychogenic polydipsia, hypercalcemia and hypokalemia

\begin{tabular}{ccc}
\hline $\mathbf{N a}(\mathrm{mEq} / \mathrm{L})$ & $\mathbf{K}(\mathrm{mEq} / \mathrm{L})$ & $\mathbf{C a}(\mathrm{mEq} / \mathrm{L})$ \\
\hline $152 \pm 0.3$ & $5.2 \pm 0.3$ & $9.0 \pm 0.3$ \\
$153 \pm 0.4$ & $6.2 \pm 0.5$ & $8.8 \pm 0.5$ \\
\hline
\end{tabular}

are also known to represent a polyuria-polydipsia (Alves et al. 2007), they were denied by considering that the values of glucose, calcium and potassium in $\mathrm{M}_{2} \mathrm{KO}$ mice were not significantly different from that of WT mice besides higher plasma osmolality and lower urine-specific gravity.

Pathohistologic findings were not detected in the kidney and other organs, and no pathological contents were detected in the urine in both mice groups. For a possibility of functional change of $\mathrm{V}_{2} \mathrm{R}$ as nephrogenic diabetes insipidus, $\mathrm{V}_{2} \mathrm{R}$ was sufficiently expressed in the kidney of both mice types and decreasing urinary volume after DDAVP treatment confirmed that $\mathrm{V}_{2} \mathrm{R}$ in $\mathrm{M}_{2} \mathrm{KO}$ mice had substantial reactivity to induce an antidiuretic effect. These findings suggest that AVP syntheses/secretion mediated by $\mathrm{M}_{2}$ receptors has a crucial role in maintaining body fluid homeostasis.

The $\mathrm{M}_{2}$ receptor is known as a Gi/o type of $\mathrm{G}$ proteincoupled receptor, which commonly yields an inhibitory effect on neurotransmitter release. In the auditory cortex and the hippocampus in the brain, it has been reported that the $\mathrm{M}_{2}$ receptor inhibited $\gamma$-amino butyric acid (GABA) release from presynaptic endings of GABAergic neurons and then indirectly caused excitation in postsynaptic neurons (Fukudome et al. 2004, Salgado et al. 2007). Indeed, GABAergic regulation in the SON (Decavel \& Van Den Pol 1990, Pirker et al. 2000) and existence of

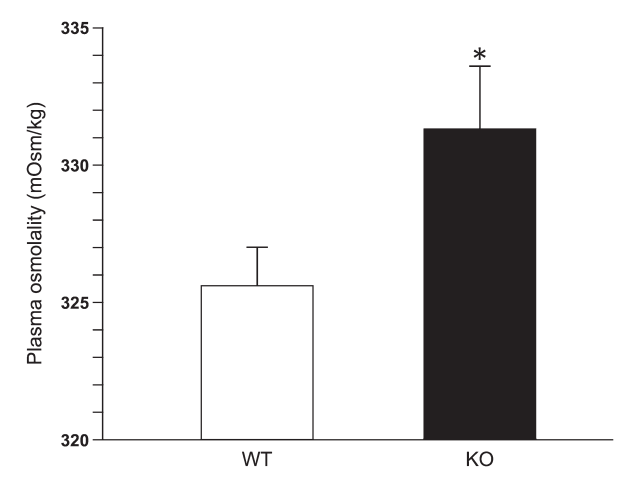

Figure 5

Plasma osmolality in WT and $\mathrm{M}_{2} \mathrm{KO}$ mice. The values are calculated by using the value of sodium, potassium, glucose and blood urea nitrogen obtained from blood tests: Calculated osmolality $=2[\mathrm{Na}]+2$ $[\mathrm{K}]+[\mathrm{GLU}] / 18+[\mathrm{BUN}] / 2.8(\mathrm{mosmol} / \mathrm{kg})$. The value in $\mathrm{M}_{2} \mathrm{KO}$ mice is significantly higher than that in WT mice $(325.6 \pm 1.4, n=13$; vs $331.3 \pm 2.3$, $n=8) .{ }^{*} P<0.05$ vs WT group. 
A
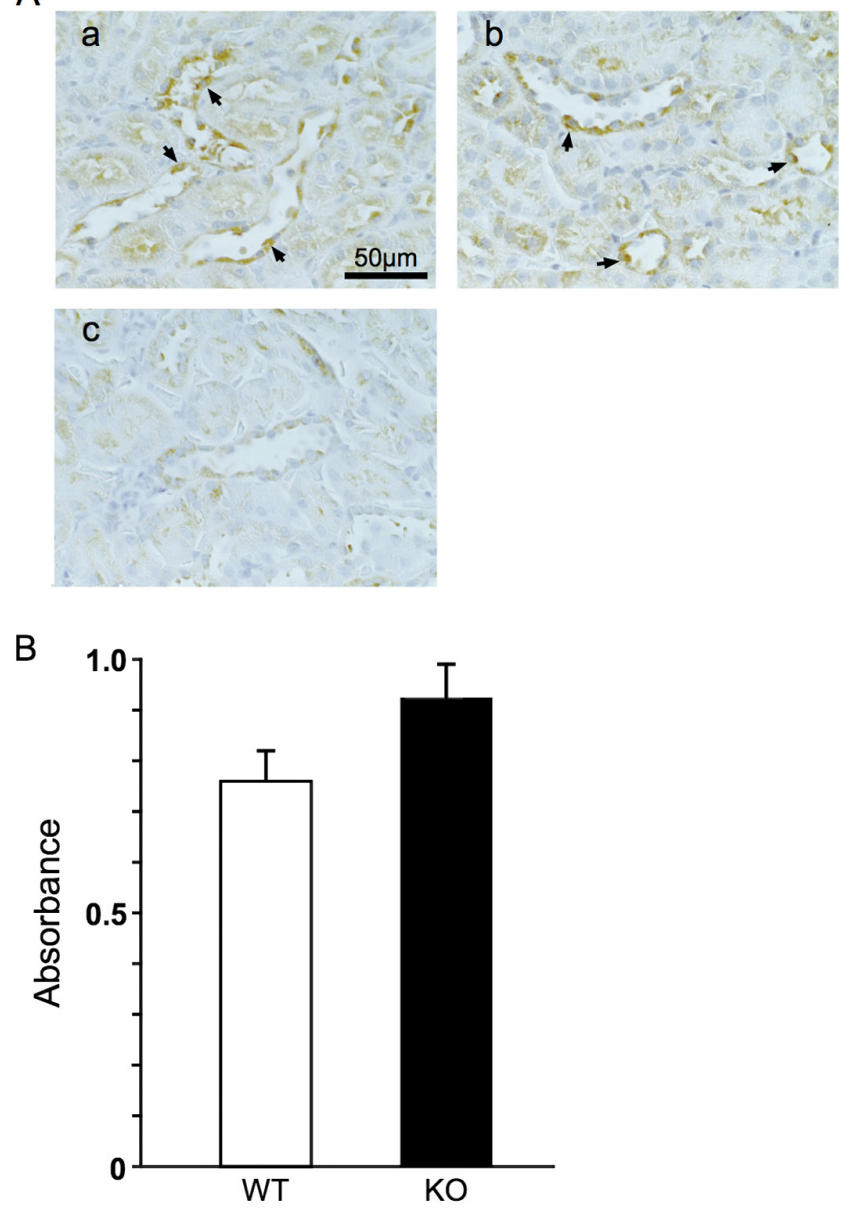

Figure 6

Expression of $\mathrm{V}_{2}$ receptor in kidney. Immunohistochemistry for $\mathrm{V}_{2}$ receptor $(A) . V_{2} R$ immunoreactivity is detected in in the tubular epithelial cells of WT (a) and $\mathrm{M}_{2} \mathrm{KO}$ mice (b). No signal is detected without the primary antibody in WT mice (c). Scale bar indicates $50 \mu \mathrm{m}$. Arrows show immunoreactive cells to anti- $\mathrm{V}_{2} \mathrm{R}$ antibody. Expression level of $\mathrm{V}_{2} \mathrm{R}$ obtained from ELISA (B). No significant difference is found between both mice groups (WT, $n=6 ; \mathrm{KO}, n=6$ ). A full color version of this figure is available at https://doi.org/10.1530/JOE-17-0630.

cholinergic nerves and muscarinic receptors around the SON (Meeker et al. 1988) have also been well documented. Moreover, Wang et al. found that two types of choline acetyltransferase (ChAT)-containing neurons, which were large, brightly fluorescent and small, dimly fluorescent, in the hypothalamus of transgenic rats of which ChAT was tagged with a fluorescent protein (Wang et al. 2015). These large ChAT neurons were observed only near the SON but not the PVN, implying existence of predominant cholinergic regulation in the SON than in the PVN. $\mathrm{M}_{2}$ receptor is likely the most common subtype among muscarinic receptors in the hypothalamus (Vilaró et al. 1993, Wei et al. 2002, Oki et al. 2005) and the SON is the hypothalamic nuclei, which highly expresses muscarinic

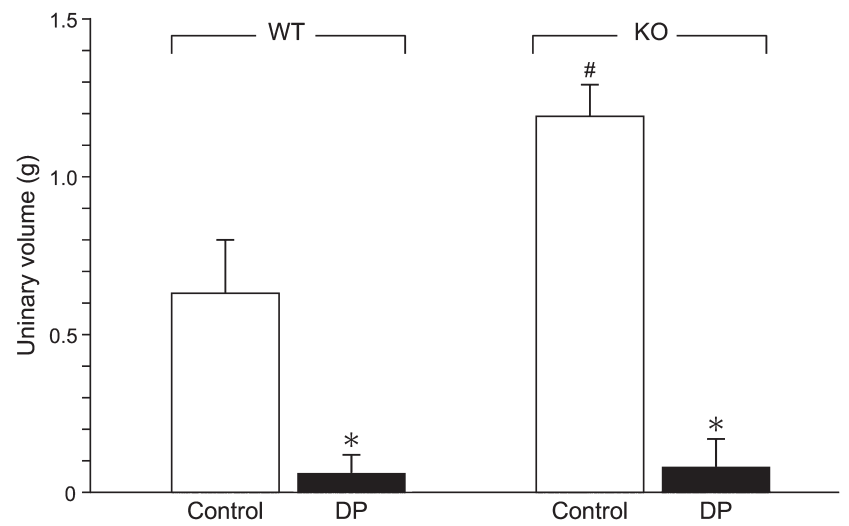

Figure 7

Effect of desmopressin on urinary volume in WT and $\mathrm{M}_{2} \mathrm{KO}$ mice. Animals are loaded with distilled water $(15 \mathrm{~mL} / \mathrm{kg}$, p.o.) and administered with saline $(5 \mathrm{~mL} / \mathrm{kg}$, i.p.) or desmopressin acetate hydrate $(1 \mu \mathrm{g} / \mathrm{kg}$, i.p.) before recording. Urinary volumes are recorded for $5 \mathrm{~h}$ while avoiding of food and drink. Control, saline-injected group; DP, desmopressin-injected group. Urinary volume of DP group is significantly decreased compared with the control group in both strains (WT, control, $n=5$; DP, $n=6$; KO, control, $n=5$; DP, $n=6$ ). ${ }^{*} P<0.05$ vs control of the corresponding mice group, $\# P<0.05$ vs control of the WT mice group.

receptors (Rotter et al. 1979). However, we were not able to find any reports referring to the difference in expression of the $\mathrm{M}_{2}$ receptor between the PVN and SON. In our preliminary experiment with WT mice (Nagano H, Matsuyama H, Iino S, Hashimoto T \& Unno T, unpublished observations), immunoreactivity for the $\mathrm{M}_{2}$ receptor were observed throughout the hypothalamus as reported previously (Vilaró et al. 1993), and it did not appear that there is notable difference between them. It might also be considered that $\mathrm{M}_{2}$ receptors expressed in other regions have an important role. For example, SFO, which transfers signal of hyperosmolality to the PVN and SON, has also been well documented to be activated via muscarinic receptors (Mangiapane \& Simpson 1979, 1983, Xu et al. 2001a, Honda et al. 2003). Particularly, the $\mathrm{M}_{2}$ receptor around the perifornical area is suggested to promote drinking (Hagan et al. 1987). Based on other studies, muscarinic stimulation activates SFO neurons by decreasing GABA release, although the subtype has not been defined ( $\mathrm{Xu}$ et al. 2001b). In sum, the $\mathrm{M}_{2}$ receptor may be expressed on GABAergic neurons rather than the membrane of MNCs and related to some signal transduction to promote AVP synthesis by decreasing GABA release from presynaptic endings. Future study should focus on which part of those regions is essential for regulation of AVP synthesis in the SON.

In summary, the present study suggested that the $\mathrm{M}_{2}$ receptor promotes AVP synthesis by MNCs in the SON region, and subsequently, plays a crucial role in 
maintaining body fluid homeostasis by controlling plasma AVP concentration. This conclusion is likely to contribute to developing new therapeutic strategies against central diabetes insipidus.

\section{Declaration of interest}

The authors declare that there is no conflict of interest that could be perceived as prejudicing the impartiality of the research reported.

\section{Funding}

This work was supported by Grants-in-Aid for Scientific Research (26450402, 15K07765, 17K08076) from the Japan Society for the Promotion of Science.

\section{Acknowledgements}

The authors thank Dr Jürgen Wess (Laboratory of Bioorganic Chemistry, National Institute of Diabetes and Digestive and Kidney Diseases, Bethesda, $M D, U S A)$ for providing the muscarinic receptor KO mice.

\section{References}

Alves FHF, Crestani CC, Resstel LBM \& Corrêa FMA 2007 Cardiovascular effects of carbachol microinjected into the bed nucleus of the stria terminalis of the rat brain. Brain Research 1143 161-168. (https://doi. org/10.1016/j.brainres.2007.01.057)

Alves FHF, Crestani CC, Busnardo C, Antunes-Rodrigues J, Gomes FV, Resstel LBM \& Corrêa FMA 2011 Hypothalamic supraoptic but not paraventricular nucleus is involved in cardiovascular responses to carbachol microinjected into the bed nucleus of stria terminalis of unanesthetized rats. Brain Research 1393 31-43. (https://doi. org/10.1016/j.brainres.2011.03.067)

Armstrong WE, Sladek CD \& Sladek JR 1982 Characterization of noradrenergic control of vasopressin release by the organ-cultured rat hypothalamo-neurohypophyseal system. Endocrinology 111 273-279. (https://doi.org/10.1210/endo-111-1-273)

Brezenoff HE, Vargas H \& Xiao Y-F 1988 Blockade of brain $\mathrm{M}_{2}$ muscarinic receptors lowers blood pressure in spontaneously hypertensive rats. Pharmacology 36 101-105. (https://doi.org/10.1159/000138365)

Bymaster FP, McKinzie DL, Felder CC \& Wess J 2003 Use of M1-M5 muscarinic receptor knockout mice as novel tools to delineate the physiological roles of the muscarinic cholinergic system. Neurochemical Research 28 437-442. (https://doi. org/10.1023/A:1022844517200)

da Silveira LTG, Junta CM, Monesi N, de Oliveira-Pelegrin GR, Passos GA \& Rocha MJA 2007 Time course of c-fos, vasopressin and oxytocin mRNA expression in the hypothalamus following long-term dehydration. Cellular and Molecular Neurobiology 27 575-584. (https:// doi.org/10.1007/s10571-007-9144-2)

Decavel C \& Van Den Pol AN 1990 GABA: a dominant neurotransmitter in the hypothalamus. Journal of Comparative Neurology $\mathbf{3 0 2}$ 1019-1037. (https://doi.org/10.1002/cne.903020423)

Dorwart WV \& Chalmers L 1975 Comparison of methods for calculating serum osmolality form chemical concentrations, and the prognostic value of such calculations. Clinical Chemistry 21 190-194.

Ehlert FJ, Griffin MT, Abe DM, Vo TH, Taketo MM, Manabe T \& Matsui M 2005 The $\mathrm{M}_{2}$ muscarinic receptor mediates contraction through indirect mechanisms in mouse urinary bladder. Journal of Pharmacology and Experimental Therapeutics 313 368-378. (https://doi. org/10.1124/jpet.104.077909)
Fitzsimons JT 1998 Angiotensin, thirst, and sodium appetite. Physiological Reviews 78 583-686. (https://doi.org/10.1152/physrev.1998.78.3.583)

Fukudome Y, Ohno-Shosaku T, Matsui M, Omori Y, Fukaya M, Tsubokawa H, Taketo MM, Watanabe M, Manabe T \& Kano M 2004 Two distinct classes of muscarinic action on hippocampal inhibitory synapses: $\mathrm{M}_{2}$-mediated direct suppression and M1/M3-mediated indirect suppression through endocannabinoid signalling. European Journal of Neuroscience 19 2682-2692. (https://doi.org/10.1111/j.0953816X.2004.03384.x)

Ghamari-Langroudi M \& Bourque CW 2004 Muscarinic receptor modulation of slow afterhyperpolarization and phasic firing in rat supraoptic nucleus neurons. Journal of Neuroscience 24 7718-7726. (https://doi.org/10.1523/JNEUROSCI.1240-04.2004)

Gomeza J, Shannon H, Kostenis E, Felder C, Zhang L, Brodkin J, Grinberg A, Sheng H \& Wess J 1999 Pronounced pharmacologic deficits in $\mathrm{M}_{2}$ muscarinic acetylcholine receptor knockout mice. PNAS 96 1692-1697. (https://doi.org/10.1073/pnas.96.4.1692)

Gribkoff VK, Christian EP, Robinson JH, Deadwyler SA \& Dudek FE 1988 Cholinergic excitation of supraoptic neurons in hypothalamic slices of rat. Neuropharmacology 27 721-727. (https://doi.org/10.1016/00283908(88)90081-0)

Hagan JJ, Tonnaer JADM \& Broekkamp CLE 1987 Cholinergic stimulation of drinking from the lateral hypothalamus: indications for $\mathrm{M}_{2}$ muscarinic receptor mediation. Pharmacology, Biochemistry and Behavior 26 771-779. (https://doi.org/10.1016/0091-3057(87)90610-1)

Hatton GI, Ho YW \& Mason WT 1983 Synaptic activation of phasic bursting in rat supraoptic nucleus neurones recorded in hypothalamic slices. Journal of Physiology 345 297-317. (https://doi.org/10.1113/ jphysiol.1983.sp014979)

Honda E, Ono K, Toyono T, Kawano H, Masuko S \& Inenaga K 2003 Activation of muscarinic receptors in rat subfornical organ neurones. Journal of Neuroendocrinology 15 770-777. (https://doi.org/10.1046/ j.1365-2826.2003.01057.x)

Igawa Y, Zhang X, Nishizawa O, Umeda M, Iwata A, Taketo M, Manabe T, Matsui M \& Andersson K 2004 Cystometric findings in mice lacking muscarinic $\mathrm{M}_{2}$ or M3 receptors. Journal of Urology 172 2460-2464. (https://doi.org/10.1097/01.ju.0000138054.77785.4a)

Iitake K, Share L, Ouchi Y, Crofton JT \& Brooks DP 1986 Central cholinergic control of vasopressin release in conscious rats. American Journal of Physiology 251 E146-E150. (https://doi.org/10.1152/ ajpendo.1986.251.2.E146)

LaCroix C, Freeling J, Giles A, Wess J \& Li Y-F 2008 Deficiency of $\mathrm{M}_{2}$ muscarinic acetylcholine receptors increases susceptibility of ventricular function to chronic adrenergic stress. American Journal of Physiology: Heart and Circulatory Physiology 294 H810-H820. (https:// doi.org/10.1152/ajpheart.00724.2007)

Landgraf R \& Ludwig M 1991 Vasopressin release within the supraoptic and paraventricular nuclei of the rat brain: osmotic stimulation via microdialysis. Brain Research 558 191-196. (https://doi. org/10.1016/0006-8993(91)90768-Q)

Leng G, Blackburn RE, Dyball REJ \& Russell JA 1989 Role of anterior peri-third ventricular structures in the regulation of supraoptic neuronal activity and neurohypophysical hormone secretion in the rat. Journal of Neuroendocrinology $135-46$. (https://doi. org/10.1111/j.1365-2826.1989.tb00074.x)

Ludwig M, Callahan MF, Neumann I, Landgraf R \& Morris M 1994 Systemic osmotic stimulation increases vasopressin and oxytocin release within the supraoptic nucleus. Journal of Neuroendocrinology 6 369-373. (https://doi.org/10.1111/j.1365-2826.1994.tb00595.x)

Mangiapane ML \& Simpson JB 1979 Pharmacologic independence of subfornical organ receptors mediating drinking. Brain Research $\mathbf{1 7 8}$ 507-517. (https://doi.org/10.1016/0006-8993(79)90710-8)

Mangiapane ML \& Simpson JB 1983 Drinking and pressor responses after acetylcholine injection into subfornical organ. American Journal of Physiology 244 R508-R513. (https://doi.org/10.1152/ ajpregu.1983.244.4.R508) http://joe.endocrinology-journals.org

https://doi.org/10.1530/JOE-17-0630 (c) 2018 Society for Endocrinology Published by Bioscientifica Ltd. Printed in Great Britain 
Martin JR 1996 Mechanisms of the cardiovascular response to posterior hypothalamic nucleus administration of carbachol. Journal of Cardiovascular Pharmacology 27 891-900. (https://doi. org/10.1097/00005344-199606000-00018)

Meeker RB, Swanson DJ \& Hayward JN 1988 Local synaptic organization of cholinergic neurons in the basolateral hypothalamus. Journal of Comparative Neurology 276 157-168. (https://doi.org/10.1002/ cne.902760202)

Michels KM, Meeker RB \& Hayward JN 1991 Muscarinic cholinergic control of vasopressin secretion from the acute hypothalamoneurohypophysial explant. Neuroendocrinology 54 219-226. (https://doi.org/10.1159/000125879)

Mori M, Tsushima H, Kamiya T \& Matsuda T 1994 Effect of muscarinic receptor modulators in the hypothalamic supraoptic nucleus of the rat. Japanese Journal of Pharmacology 66 413-419. (https://doi. org/10.1254/jjp.66.413)

Oki T, Takagi Y, Inagaki S, Taketo MM, Manabe T, Matsui M \& Yamada S 2005 Quantitative analysis of binding parameters of $[3 \mathrm{H}]$ $\mathrm{N}$-methylscopolamine in central nervous system of muscarinic acetylcholine receptor knockout mice. Brain Research: Molecular Brain Research 133 6-11. (https://doi.org/10.1016/j.molbrainres.2004.09.012)

Oldfield BJ, Hards DK \& McKinley MJ 1991 Projections from the subfornical organ to the supraoptic nucleus in the rat: ultrastructural identification of an interposed synapse in the median preoptic nucleus using a combination of neuronal tracers. Brain Research $\mathbf{5 5 8}$ 13-19. (https://doi.org/10.1016/0006-8993(91)90708-4)

Paxinos G \& Franklin K 2004 Paxinos and Franklin's the Mouse Brain in Stereotaxic Coordinates. Cambridge, MA, USA: Academic Press.

Pirker S, Schwarzer C, Wieselthaler A, Sieghart W \& Sperk G 2000 GABAA receptors: immunocytochemical distribution of 13 subunits in the adult rat brain. Neuroscience 101 815-850. (https://doi.org/10.1016/ S0306-4522(00)00442-5)

Pow DV \& Morris JF 1989 Dendrites of hypothalamic magnocellular neurons release neurohypophysial peptides by exocytosis. Neuroscience 32 435-439. (https://doi.org/10.1016/0306-4522(89)90091-2)

Rao ZR, Yamano M, Wanaka A, Tatehata T, Shiosaka S \& Tohyama M 1987 Distribution of cholinergic neurons and fibers in the hypothalamus of the rat using choline acetyltransferase as a marker. Neuroscience $\mathbf{2 0}$ 923-934. (https://doi.org/10.1016/0306-4522(87)90253-3)

Rotter A, Birdsall NJ, Burgen AS, Field PM, Hulme EC \& Raisman G 1979 Muscarinic receptors in the central nervous system of the rat. I. Technique for autoradiographic localization of the binding of $[3 \mathrm{H}]$ propylbenzilylcholine mustard and its distribution in the forebrain. Brain Research 180 141-165. (https://doi.org/10.1016/0165-0173(79)90002-X)

Salgado H, Bellay T, Nichols JA, Bose M, Martinolich L, Perrotti L \& Atzori M 2007 Muscarinic $\mathrm{M}_{2}$ and M1 receptors reduce GABA release by $\mathrm{Ca} 2+$ channel modulation through activation of PI3K/ Ca2+-independent and PLC/Ca2+-dependent PKC. Journal of Neurophysiology 98 952-965. (https://doi.org/10.1152/jn.00060.2007)

Shen E \& Sun X 1995 Endogenous acetylcholine-induced Fos expression in magnocellular neurosecretory neurons in the supraoptic nucleus of the rat hypothalamus. Neuroscience Letters 195 191-194. (https://doi. org/10.1016/0304-3940(95)11816-F)

Shen E, Dun SL, Ren C, Bennett-Clarke C \& Dun NJ 1992 Hypotension preferentially induces c-fos immunoreactivity in supraoptic vasopressin neurons. Brain Research 593 136-139. (https://doi. org/10.1016/0006-8993(92)91275-J)

Sherman TG, McKelvy JF \& Watson SJ 1986 Vasopressin mRNA regulation in individual hypothalamic nuclei: a northern and in situ hybridization analysis. Journal of Neuroscience 6 1685-1694.
Struckmann N 2003 Role of muscarinic receptor subtypes in the constriction of peripheral airways: studies on receptor-deficient mice. Molecular Pharmacology 64 1444-1451. (https://doi.org/10.1124/ mol.64.6.1444)

Takahashi A, Ishimaru H, Ikarashi Y, Kishi E \& Maruyama Y 2001 Opposite regulation of body temperature by cholinergic input to the paraventricular nucleus and supraoptic nucleus in rats. Brain Research 909 102-111. (https://doi.org/10.1016/S0006-8993(01)02642-7)

Uchiyama T \& Chess-Williams R 2004 Muscarinic receptor subtypes of the bladder and gastrointestinal tract. Journal of Smooth Muscle Research 40 237-247. (https://doi.org/10.1540/jsmr.40.237)

Vilaró MT, Mengod G \& Palacios JM 1993 Advances and limitations of the molecular neuroanatomy of cholinergic receptors: the example of multiple muscarinic receptors. Progress in Brain Research 98 95-101.

Wang L, Ennis M, Szabó G \& Armstrong WE 2015 Characteristics of GABAergic and cholinergic neurons in perinuclear zone of mouse supraoptic nucleus. Journal of Neurophysiology 113 754-767. (https:// doi.org/10.1152/jn.00561.2014)

Wei J, Walton EA, Milici A \& Buccafusco JJ 2002 m1-m5 muscarinic receptor distribution in rat CNS by RT-PCR and HPLC. Journal of Neurochemistry 63 815-821. (https://doi.org/10.1046/j.14714159.1994.63030815.x)

Wotjak CT, Kubota M, Liebsch G, Montkowski A, Holsboer F, Neumann I \& Landgraf R 1996 Release of vasopressin within the rat paraventricular nucleus in response to emotional stress: a novel mechanism of regulating adrenocorticotropic hormone secretion? Journal of Neuroscience 16 7725-7732.

Wotjak CT, Naruo T, Muraoka S, Simchen R, Landgraf R \& Engelmann M 2001 Forced swimming stimulates the expression of vasopressin and oxytocin in magnocellular neurons of the rat hypothalamic paraventricular nucleus. European Journal of Neuroscience 13 2273-2281. (https://doi.org/10.1046/j.0953-816x.2001.01613.x)

Xiao YF \& Brezenoff HE 1988 The role of $\mathrm{M}_{2}$ muscarinic receptors in the posterior hypothalamus in the pressor response to intracerebroventricularly-injected neostigmine. Neuropharmacology $\mathbf{2 7}$ 1061-1065. (https://doi.org/10.1016/0028-3908(88)90068-8)

Xu Z, Pekarek E, Ge J \& Yao J 2001a Functional relationship between subfornical organ cholinergic stimulation and cellular activation in the hypothalamus and AV3V region. Brain Research 922 191-200. (https://doi.org/10.1016/S0006-8993(01)03166-3)

Xu S-H, Honda E, Ono K \& Inenaga K 2001b Muscarinic modulation of GABAergic transmission to neurons in the rat subfornical organ. American Journal of Physiology: Regulatory, Integrative and Comparative Physiology 280 R1657-R1664. (https://doi.org/10.1152/ ajpregu.2001.280.6.R1657)

Xu Z, Torday J \& Yao J 2003 Functional and anatomic relationship between cholinergic neurons in the median preoptic nucleus and the supraoptic cells. Brain Research 964 171-178. (https://doi. org/10.1016/S0006-8993(02)03800-3)

Yamamoto G, Kai N, Shirasaki T, Soeda F \& Takahama K 2009 Novel method of sequential urine collection and recording in freely moving mice. Nihon Yakurigaku Zasshi: Folia Pharmacologica Japonica 133 332-336. (https://doi.org/10.1254/fpj.133.332)

Zaninetti M, Tribollet E, Bertrand D \& Raggenbass M 2002 Nicotinic cholinergic activation of magnocellular neurons of the hypothalamic paraventricular nucleus. Neuroscience 110 287-299. (https://doi. org/10.1016/S0306-4522(01)00536-X)

Zhang L 2006 Cholinergic receptor knockout mice. In Animal Models of Cognitive Impairment, pp 199-221. Eds ED Levin \& JJ Buccafusco. Boca Raton, FL, USA: CRC Press/Taylor \& Francis.

Received in final form 4 March 2018

Accepted 21 March 2018

Accepted Preprint published online 21 March 2018 http://joe.endocrinology-journals.org

https://doi.org/10.1530/JOE-17-0630 (c) 2018 Society for Endocrinology Published by Bioscientifica Ltd. Printed in Great Britain 